\title{
Influence of a cage farming on the population of the fish species Apareiodon affinis (Steindachner, 1879) in the Chavantes reservoir, Paranapanema River SP/PR, Brazil
}

\author{
Influência de uma piscicultura em tanques-rede na população \\ da espécie de peixe Apareiodon affinis (Steindachner, 1879) no \\ reservatório de Chavantes, rio Paranapanema SP/PR, Brasil
}

Heleno Brandão ${ }^{1}$, Javier Lobón-Cerviá ${ }^{2}$ Igor Paiva Ramos ${ }^{3}$, Ana Carolina Souto ${ }^{1}$,

André Batista Nobile ${ }^{1}$, Érica de Oliveira Penha Zica ${ }^{1}$ and Edmir Daniel Carvalho ${ }^{1}$

${ }^{1}$ Laboratório de Biologia e Ecologia de Peixes, Departamento de Morfologia,

Instituto de Biociências de Botucatu, Universidade Estadual Paulista - UNESP,

Distrito de Rubiāo Junior, s/n, CEP 18618-970, Botucatu, SP, Brazil

e-mail: heleno_brandao@hotmail.com; acarolsouto@gmail.com;

andrenobile@hotmail.com; ericazica@hotmail.com; carvalho@ibb.unesp.br

${ }^{2}$ Museo Nacional de Ciencias Naturales - CSIC, Sede: c/José Gutiérrez Abascal, 2. 28006 Madrid, Espanha

e-mail: monl178@mncn.csic.es

${ }^{3}$ Centro de Ciências Biológicas e da Saúde, Universidade Estadual do Oeste do Paraná -UNIOESTE,

CEP 85819-110, Cascavel, PR, Brazil

e-mail: igor@ibb.unesp.br

\begin{abstract}
Aim: The aim of the present study was to evaluate the diet and biological attributes of the population of Apareiodon affinis residing near net-cage fish farming activities in the Chavantes reservoir. Methods: Samples were collected from two populations: one near the net cages (NC) and one from an area not influenced by these cages denominated the "reference site" (RS). Monthly sampling was carried out from Mar/ 2008 to Feb/ 2009. Fish were caught with a standardized effort using gill nets deployed for 14 hours. After all individuals were measured (standard length) and weighed (total weight, carcass weight, body weight without gonads). To determine the composition of the diet, the alimentary index was calculated (AI). We also calculated the length-weight relationship, condition factor, gonad-somatic index (GSI) and reproductive potential. Results: A total of 3050 individuals were caught. The results of the (AI) revealed that the item detritus was the main food used for populations of $A$. affinis studied in two areas ( $\mathrm{NC}=73.1 \%$ and $\mathrm{RS}=95.7 \%)$. The use of feed on diet $A$. affinis was recorded for the populations of $\mathrm{NC}$ adding $(20.5 \%)$ of the total items consumed by the population. The resident populations residing near net-cage showed higher condition factor and more reproductive period. Conclusions: The results show the ability of the species to benefit from the input of organic matter from fish farming activities, inserting a new item in their diet (ration). This work indicates that the species $A$. affinis managed to establish near netcage, allocating enough energy to increase their reproductive period and maintain viable populations close to net-cage, evidenced by the high abundance. This study suggests that systems of fish farming in net-cage influence diet and biological attributes of the species A. affinis residents Chavantes reservoir, Brazil.
\end{abstract}

Keywords: fish, Paradontidae, biological attributes, fish farming impacts, teleost.

Resumo: Objetivo: $\mathrm{O}$ objetivo deste estudo foi avaliar a influência de uma piscicultura em tanques-rede na dieta e nos atributos biológicos da espécie Apareiodon affinis na represa de Chavantes. Métodos: Foram coletadas amostras da população ao redor dos tanquesrede (TR) e comparada com uma área sem esta influência, denominada controle (CT). As amostragens foram realizadas mensalmente de mar/2008 até fev/2009. Os peixes foram capturados utilizando-se de rede de espera com esforço padronizado, expostas por 14 horas. Todos os peixes foram medidos (comprimento padrão) e pesados (peso total, peso da carcaça, peso corporal sem as gônadas). Para determinar a composição da dieta, foi calculado o índice alimentar (IAi). Também foram calculados a relação peso comprimento, fator de condição, índice gonodossomático (IGS) e o potencial reprodutivo. Resultados: Um total de 3050 indivíduos foi capturado. Os resultados do (IAi) revelou que o item 
detrito, foi o principal alimento utilizado pelas populaçóes de $A$. affinis nas duas áreas estudas (TR $=73,1 \%$ e CT $=95,7 \%)$. A utilização da ração na dieta de $A$. affinis foi registrada para as populaçóes do TR somando $(20,5 \%)$ do total de itens consumidos pelas populaçóes. As populaçóes residentes ao redor dos tanques-rede apresentaram maiores valores de fator de condição e período reprodutivo. Conclusão: Os resultados mostram a habilidade da espécie em se beneficiar da entrada de matéria orgânica proveniente das atividades da piscicultura, inserindo um novo item em sua dieta (ração). Este trabalho indica que a espécie $A$. affinis conseguiu se estabelecer ao redor dos tanques-rede, alocando energia suficiente para aumentar o seu período reprodutivo e manter suas populaçóes viáveis ao redor dos tanques-rede, comprovado pela elevada abundancia. Este estudo sugere que os sistemas de pisciculturas em tanques-rede influenciam a dieta e os atributos biológicos da espécie $A$. affinis residentes na represa de Chavantes, Brasil.

Palavras-chave: peixe, Paradontidae, atributos biológicos, impactos de piscicultura, teleósteos.

\section{Introduction}

In recent decades, Brazilian hydrographic basins have been dammed in order to generate hydroelectricity, according to government guidelines, to meet the growing energy demanding. However, the artificial lakes that result from these projects have caused damage to native flora and fauna, as well as severe socioeconomic problems (Naik et al., 2011; Agostinho et al., 2011).

Fish communities have been suffering from other impacts that reduce their diversity, such as the introduction of non-native species (Latini and Petrere Junior, 2004; Zanatta et al., 2010). Furthermore, encouraged by the government, cage-farming activities are currently expanding in reservoirs of hydroelectric plants, where the inclusion of these systems may be a new source of impact on the ichthyofauna of reservoirs (HenrySilva and Cardoso 2008; Lachi and Sipaúba-Tavares, 2008; Brasil, 2009, 2011). Nevertheless, the possibility to increase aquaculture production in the future seems to be very high (Gjedrem, 2012).

According to the Agência Paulista de Tecnologia dos Agronegócios (APTA, 2008), there are 360 fish farmers in the middle Paranapanema River region, and at least 40 species of freshwater fish in Brazil are used in aquaculture, which represents only $1.5 \%$ of all known species (Godinho, 2007). Fish farming activities have been increasing and becoming an important source of protein for human consumption. Brazil has a great potential for the development of aquaculture, due to its vast territory and favorable climate conditions, which is also internationally acknowledged (Pavanelli et al., 2008).

Fish farming in cages provides resources in the form of matter and energy for aquatic trophic webs, serving as an attraction for many organisms (Nickell et al., 2003; Machias et al., 2004; Giannoulaki et al., 2005; Kutti, 2008; SalesLuís et al., 2009; Zambrano et al., 2010), through the release of leftover ration from the development of the activity, which also indirectly contributes to the growth of algae (Mannino and Sara, 2008; Borges et al., 2010). Håkanson et al. (1998) and Håkanson (2005) argue that part of the food ingested by farmed fish is eliminated as excreta (feces and metabolites), which is also utilized by resident fish fauna occupying areas close to fish farming cages. Thus, part of this ration is not fully exploited by organisms in the farming cage, and therefore lost to the aquatic environment and may be used by local biota (Beveridge et al., 1991).

The physical structure of net cages may serve as shelter and refuge to different components of the biota (Beveridge, 1984, 1996), which might lead to environmental problems (Dalsgaard and Krause-Jensen, 2006). The communities of organisms reflect the conditions of the hydrographic basin better than any physical-chemical variable of water quality as the organisms respond to the full range of biogeochemical factors of the environment (Karr and Chu, 2000). Fish are highly sensitive components of aquatic ecosystems and have several attributes that make them useful as biological indicators of the conservation status of environments (Simon and Lyons, 1995).

Studies with fish can present environmental changes associated with the watershed. Thus, some attributes of the community, such as abundance and trophic structure, are used to assess the environmental conditions in which fish live (Karr, 1981). These will also have great biological and socioeconomic importance, justifying their use in biological monitoring programs (Roset et al., 
2007). This study used the fish species, Apareiodon affinis (Steindachner, 1879), belonging to family Parodontidae Characiformes, which presents a wide geographical distribution in the neotropical region (Nelson, 1994; Reis et al., 2003), and is one of the most abundant fish species in the Paranapanema River basin (Dias and Garavello, 1998; Britto and Carvalho, 2006; Teixeira and Bennemann, 2007; Brandão et al., 2009).

The species is specifically characterized as detritivores (Casatti et al., 2003) and omnivorous (Vidotto-Magnoni and Carvalho, 2009). It is considered small and of no commercial value, being used only as bait for professional and amateur fishing (Shibatta et al., 2002; Ratton et al., 2003; Bialetzki and Nakatani, 2004). Moreover, this species is a major prey for numerous piscivorous fishes (Bialetzki et al., 1998) and negative impacts on this species may also have consequences on higher trophic levels (Gurgel, 2004; Santos et al. 2006).

This study aimed to evaluate the influence of fish farming in Chavantes reservoir, Paranapanema River on the diet and biological attributes of the fish species Apareiodon affinis captured around a system of fish farm cages, compared to a reference site (not influenced by a cage farm system).

\section{Material and Methods}

The Chavantes reservoir $\left(\mathrm{S} 23^{\circ} 22^{\prime} \mathrm{W} 49^{\circ} 36^{\prime}\right)$ is located in the medium stretch of the Paranapanema River at the border of São Paulo (SP) and Paraná (PR) States. The reservoir is located at $480 \mathrm{~m}$ above sea level, with a maximum depth of 70 to $90 \mathrm{~m}$, a total volume of $9410 \times 106 \mathrm{~m}^{3}$ and an area of $400 \mathrm{~km}^{2}$ (Duke Energy, 2002).

The study was conducted within a private enterprise for the breeding of tilapia, Oreochromis niloticus in cages, in a lentic segment of the reservoir, located between the municipalities of Ipaussu and Chavantes (SP). To carry out the study, two sites were selected for the study - the first one close to the area where the fish farm system was installed designated as net cage site (NC). The second site, located in a stretch below the NC, was designated as reference site (RS), located at geographic coordinates $23^{\circ} 7^{\prime} 56.89^{\prime \prime} \mathrm{S}$ and $49^{\circ} 36^{\prime} 13.24^{\prime \prime} \mathrm{W}$, approximately $3 \mathrm{~km}$ from NC (Figure 1). The two study sites were bordered by rocks, fragments of mesophytic forests and some areas of aquatic macrophytes.

The fish farm studied has been operating since the beginning of 2008. It is classified as medium size and has about 200 net cages, each one with a

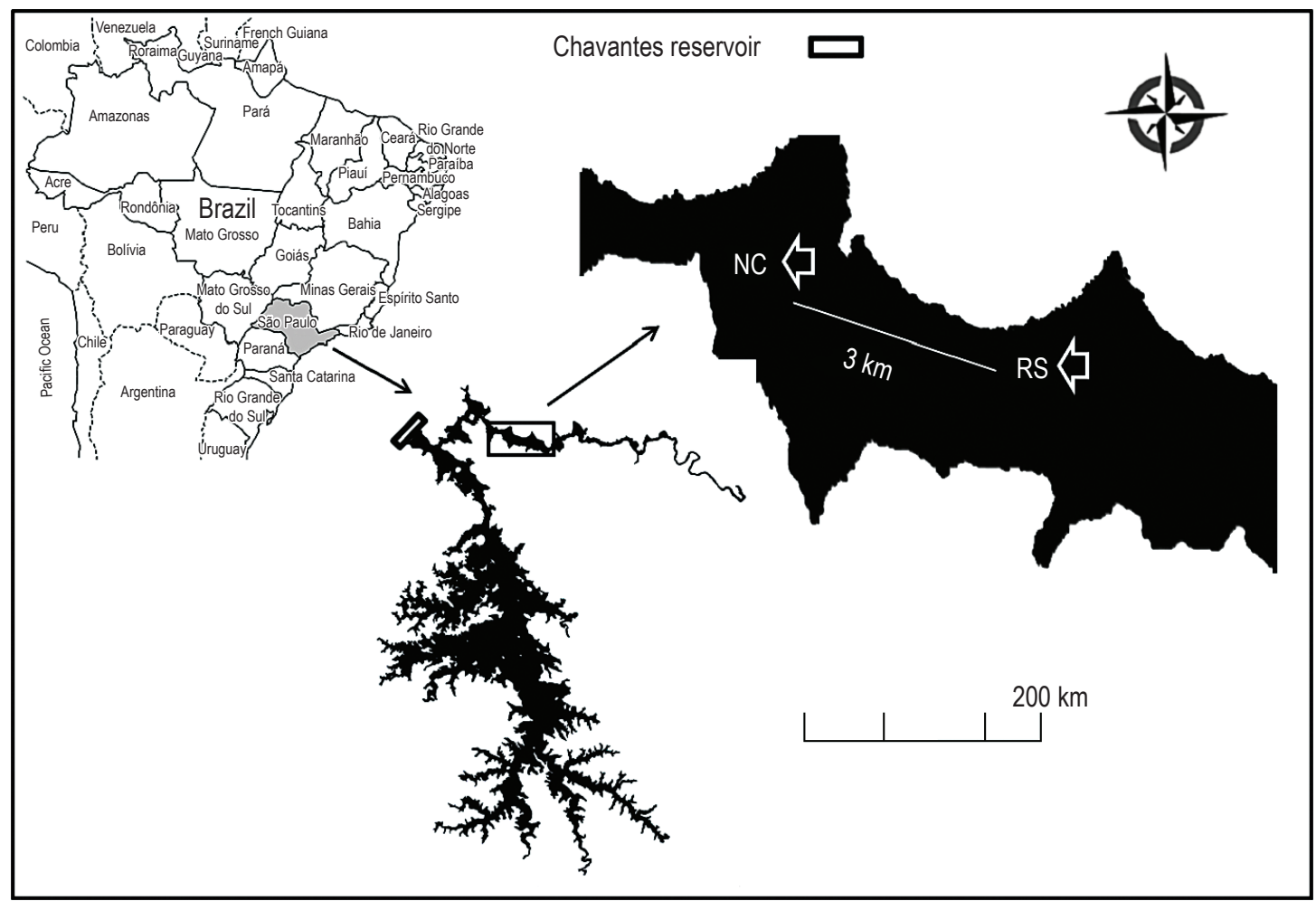

Figure 1. Political map of Brazil highlighting (gray color) the state of São Paulo, where it entered the Chavantes reservoir in the middle Paranapanema River SP/PR. (arrow) Study site - a system of fish farming in net cages (NC) and reference site (RS). (Source: Satellite image of GoogleEarth - DigitalGlobe; IBGE). 
volume ranging from 6 to $18 \mathrm{~m}^{3}$. The population of $A$. affinis has increased in the surrounding area of the fish farm since the beginning of its construction and has continuously grown in the area near the net cages.

The fish were collected monthly (License no Ibama Register: 2629349) at the two sites from March 2008 to February 2009 in normal environmental conditions. Fish were captured with gill nets, grouped in three sets with five nets each (mesh sizes $=3$ to $14 \mathrm{~cm}$, not opposite knots and height from 1.44 to $2.20 \mathrm{~m}$ ). Nets were set at 5:00 PM and removed at 6:00 AM (exposure time of 14 hours). Right after capture all individuals were measured and weighed.

Hydrological and environmental data for this reservoir, such as rainy and dry seasons (cumulative monthly rainfall) were obtained from the Department of Hydrobiology of Duke Energy - Generation Paranapanema. Voucher specimens were deposited in the Laboratory of Biology and Genetics of Fish, Institute of Biosciences, UNESP, Botucatu, Brazil.

The species biometric data were determined using an ichthyometer and precision balance. Stomach contents were analyzed under a stereomicroscope, identified to the most detailed taxonomic level possible and weighed (wet weight) on a scale with $0.0001 \mathrm{~g}$ of approximation. The results were expressed as the frequency of occurrence and gravimetric method, generating an index that shows the main food items of the diet of a given population (Kawakami and Vazzoler, 1980), adapted by Hahn et al. (1998): AI = Fi $\times$ Wi x 100/ $\mathrm{Fi} \times \mathrm{Wi}$, when: $\mathrm{AI}=$ alimentary index; $\mathrm{i}=1.2 \ldots \mathrm{n}$, food items, $\mathrm{Fi}=$ frequency of occurrence of item $\mathrm{i}(\%)$; $\mathrm{Wi}=$ wet weight of item $\mathrm{i}(\%)$. The identification of food items was performed based on identification keys (Strixino and Strixino, 1982; Merritt and Cummins, 1996; Costa et al., 2006).

The sex was determined through macroscopic visualization of the gonads (Veregue and Orsi, 2003). The calculation of the length-weight relationship was based on Santos (1978) and King (2007), as follows equation: $\mathrm{W}_{t}=\phi^{*} \mathrm{~L}^{\theta}$ where $\mathrm{W}_{\mathrm{t}}=$ total weight of the individual $(\mathrm{g})$ and/or carcass weight $\left(\mathrm{W}_{c}\right), \phi=$ parameter that measures the degree of fish fattening; $\mathrm{L}_{\mathrm{s}}=$ standard length $(\mathrm{cm})$ and $\phi=$ parameter that defines the type of growth of the species with the aid of the STATISTICA 7 program (ZAR, 1984).

The condition factor was obtained from the mathematical expression of length-weight relationship using the value of $\theta$ (type of specie's growth) calculated for the two sections combined. To calculate the individual condition factor $(\mathrm{K})$ the mathematical expression $\mathrm{K}=\mathrm{Wt} / \mathrm{Ls}^{\theta}$, and $\mathrm{K}=$ condition factor was applied, according to Vazzoler (1996). The values obtained for the condition factor were tested using the nonparametric Mann-Whitney test $(\mathrm{U}$ Test; $\mathrm{p}<0.0001)$ to determine possible statistical differences between sexes and locations (NC and RS).

To investigate the occurrence of reproductive stages, we examined seasonal variations in the gonads with the gonadosomatic index (GSI): $\mathrm{GSI}=\mathrm{Wg} / \mathrm{Wt} * 100$, where, $\mathrm{Wg}=$ weight of gonads and $\mathrm{wt}=$ weight total (Vazzoler, 1996). To obtain the reproductive potential, counts were performed in oocytes of 437 females from NC and 219 from RS using stereomicroscopy, utilizing a previouslyfixed ovary sample from each individual. The morphometry of oocytes was performed as follows: Ten oocyte units from five samples of monthly individuals were randomly selected to determine the mean biometrics area, and horizontal and vertical diameter, with the aid of the QWin Lite 3.1 and LAZ V3 programs (Leica Application Suite).

For all statistical analysis, differences between variables were considered significant when $\mathrm{p}<0.05$ ( $5 \%$ significance level).

\section{Results}

We collected a total of 3,050 specimens of A. affinis (voucher, LBP 4793); 2,183 were collected in the NC, of which 799 had their stomach contents analyzed; and 867 were collected in the RS, of which 575 had their stomach contents analyzed. The most important item of the diet in the two selected study sites ( $\mathrm{NC}$ and $\mathrm{RS}$ ) was detritus ( $\mathrm{AI}=73.1 \%$ and 95.7\% respectively). The remains ration was the second most important item in the $\mathrm{NC}(\mathrm{AI}=23 \%)$, and for the RS, the second important item was vegetal fragments $(\mathrm{AI}=4.3 \%)$ (Figure 2$)$.

The length-weight relationship was examined in two manners; firstly, we considered the total wet weight of the fish and, secondly, we considered the wet weight of carcasses. Negative allometric growth was observed in both tests for this species (Table 1). The values of the condition factor of the species were higher in the NC, where the wet weight and weight of the carcasses suggest a strong effect of the net cages on the physical condition of the fish (Figure 3a, b). Nevertheless, an analysis of the condition factor, considering the weight of the gonads, did not demonstrate statistical differences 

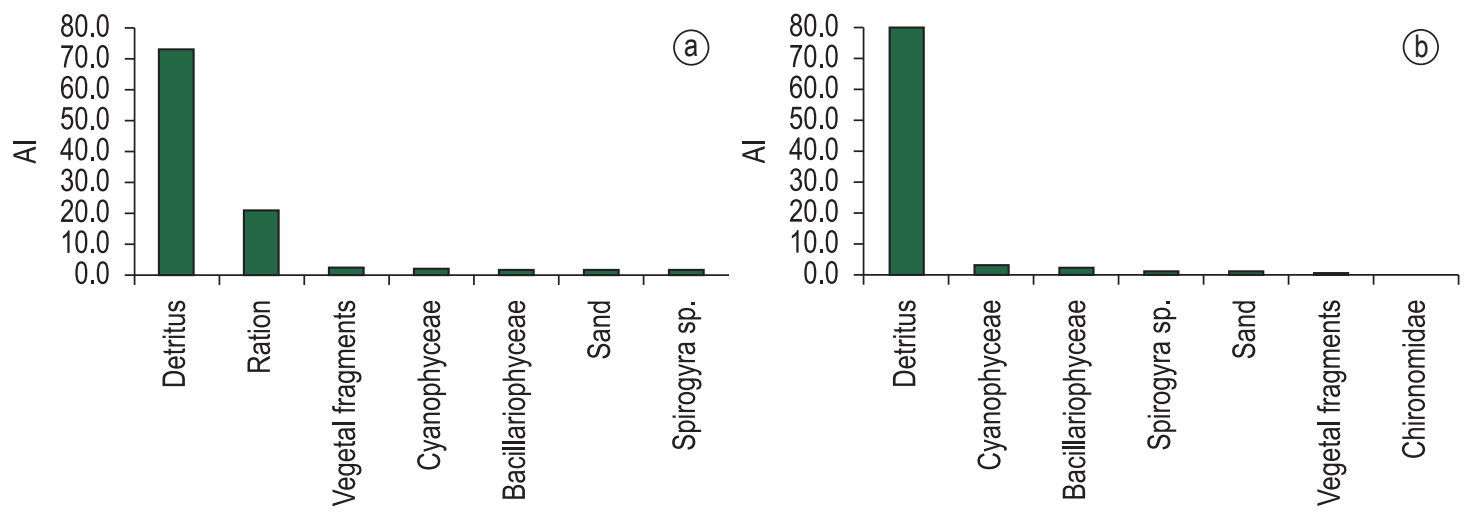

Figure 2. Alimentary Index (AI) of A. affinis in NC (a) and RS (b), collected in Chavantes reservoir, Paranapanema River SP/PR.

Table 1. Relationship weight-length in the species $A$. affinis in sites $(\mathrm{NC})=$ Net Cage and $(\mathrm{RS})=$ Reference Site in the Chavantes' reservoir, Paranapanema River SP/PR, where: $(\mathrm{n})=$ number of analyzed specimens, $(\phi)=$ condition factor, $(\theta)=$ growth type, $\left(r^{2}\right)=$ determination coefficient, $(p)=$ significance level, *values statistically different $\mathrm{p}=<0.0001$.

\begin{tabular}{lccccc}
\hline \multicolumn{1}{c}{ Variable } & $\mathbf{n}$ & $\phi$ & $\theta$ & $\mathbf{r}^{\mathbf{2}}$ & $\mathbf{p}$ \\
\hline Wet weigth (NC) & 2,612 & 0.95 & 2,192 & 0.65 & ${ }^{*}<0.0001$ \\
Carcass weigth (NC) & 2,612 & 0.99 & 2,234 & 0.66 & ${ }^{*}<0.0001$ \\
Wet weigth (RS) & 829 & 0.07 & 2,404 & 0.71 & ${ }^{*}<0.0001$ \\
Carcass weigth (RS) & 829 & 0.09 & 2,254 & 0.65 & ${ }^{*}<0.0001$ \\
\hline
\end{tabular}

between the two study sites (Mann-Whitney test $\mathrm{U} ; \mathrm{p}=0.2$ ) (Figure 3c).

The mean monthly gonad-somatic index (GSI) exhibited substantial differences among the months and permitted the identification of the reproductive period. Both females and males showed the highest GSI during an apparently longer period in the NC. The reproductive period in the NC lasted from October to January, and attained the highest GSI values for both sexes in January, with a decline in February. Maximum gonad values for females in the RS occurred between October and December and showed the highest values, for both sexes, in November and a decline for females in January (Figure 4a-c).

During the study period, smaller oocytes were observed in the NC for this species, presenting monthly averages of $0.40 \mathrm{~mm}$ to $0.79 \mathrm{~mm}$ for the horizontal diameter, $0.44 \mathrm{~mm}$ to $0.76 \mathrm{~mm}$ for the vertical diameter and an area of $0.14 \mathrm{~mm}$ to $0.41 \mathrm{~mm}$. In contrast, in the RS horizontal diameters of $0.47 \mathrm{~mm}$ to 0.80 were recorded, and $0.42 \mathrm{~mm}$ to $0.77 \mathrm{~mm}$ in diameter, $0.18 \mathrm{~mm}$ in vertical diameter, and $0.41 \mathrm{~mm}$ in area. However, the species had a higher reproductive potential at the NC site; for the NC, the maximum fertility in the population ranged from 12,816 to 78,557 oocytes and for RS ranged from 9,327 to 49,738 oocytes (Table 2).

\section{Discussion}

This study demonstrates differences in abundance, biomass and biological attributes between the population of $A$. affinis sampled around the net cages and also from the reference site. The diet at both sites was based on detritus, however, populations of NC used the ration from fish farming as part of their diet, thus added a new food item in your diet (Carvalho et al., 2012). Energy transmission is confirmed by high abundance of $A$. affinis feeding on remains ration around the net cages.

Opportunistic consumption is considered an important tactic for successful colonization in habitats affected by anthropogenic activities, allowing species to maximize energy input due to the supply and quality of available food. Attraction to the area under the influence of fish farming is likely related to the secondary input of matter and energy. Thus, one may infer that fish seek areas near net cages due to the availability of food of an allochthonous (remains of ration) or autochthonous (algae, zoobenthos and fish) origin.

Fish farming in cages releases resources, such as matter and energy for the aquatic tropic webs, 


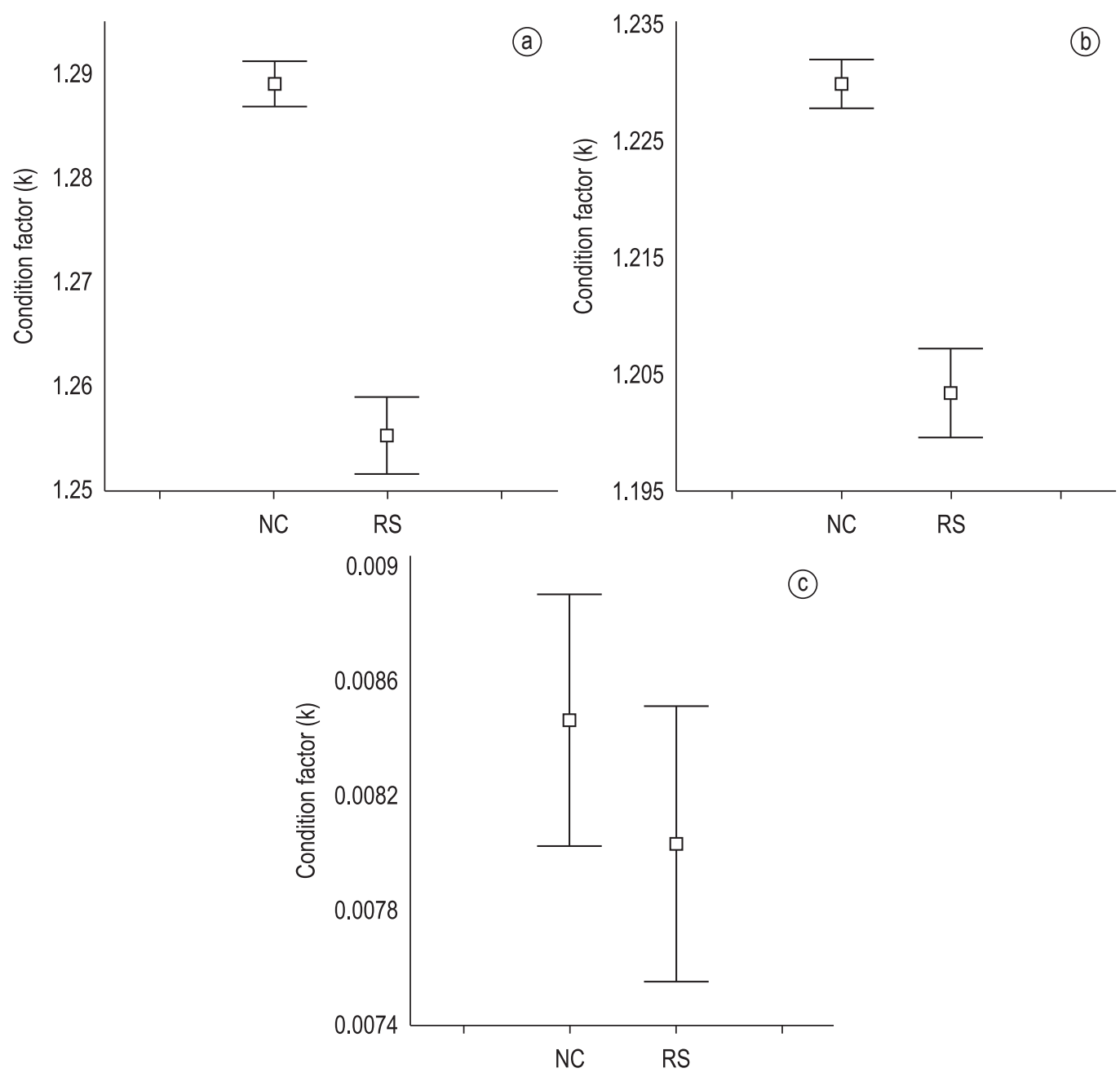

Figure 3. "Mean-Plot" - Individual condition factor of A. affinis for net cage site (1) and reference site (2) where: a) populations considering the total weight, b) carcass weight and c) gonad weight in Chavantes reservoir, Paranapanema River SP/PR (values significantly different Mann-Whitney test (U Test; $\mathrm{p}<0.0001$ ).

serving as an attractant for many organisms (Beveridge, 2004), through discharge of remains of ration from the development of the activity (feeding). These effluents have different degrees of impact on the aquatic ecosystem, depending on the amount released, dilution, and time of release and dispersal capacity in the water column (Carroll et al., 2003; Yokoyama, 2003). The input of leftover ration and feces from fish farming activities becomes the primary source of nutrients in the surrounding aquatic ecosystems (Ono and Kubitza, 2003) and the increased availability of food resources can cause changes in the potential productivity of aquatic organisms through trophic interactions.

The physical condition for both wet weight and carcasses appeared higher in the fish farm population, suggesting that this process might be caused by the additional food supply from the fish farm, which might induce both higher growth rates and earlier maturity (Cushing, 1981; Gomiero and Braga, 2005). Nevertheless, the physical condition for the body weight without gonads showed no obvious differences among females. This is probably due to larger investment of energy (i.e., lipids), and additional food supply.

The population of the fish farm also showed a prolonged reproductive period, in the NC compared within RS populations. This also suggests that the fish farm population might have some reproductive advantages. When comparing reproductive potentials, it is possible to observe higher values in NC. However, the population of the NC produced smaller oocytes during the study period. This might be related to the reproductive strategy of the species, characterized by small oocytes, which may facilitate release to the environment in a shorter time and in larger quantities. Agostinho et al. (2007) reported that small eggs and rapid development are components of the reproductive strategy of fish in 


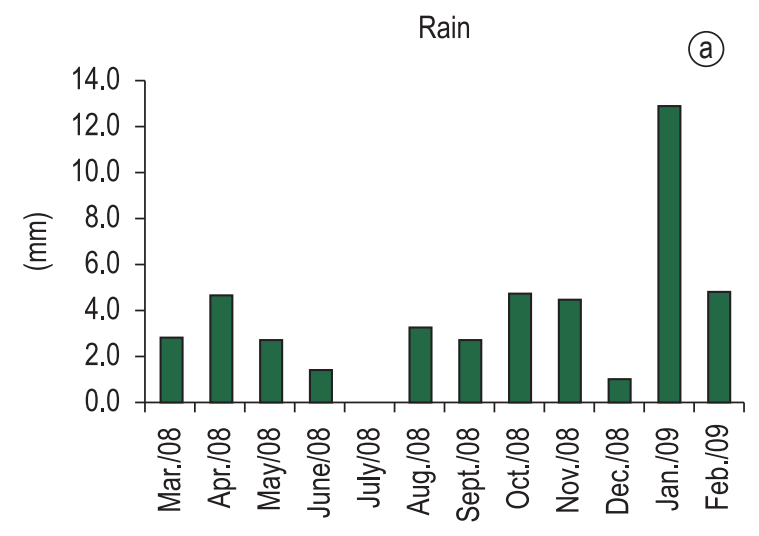

(b)

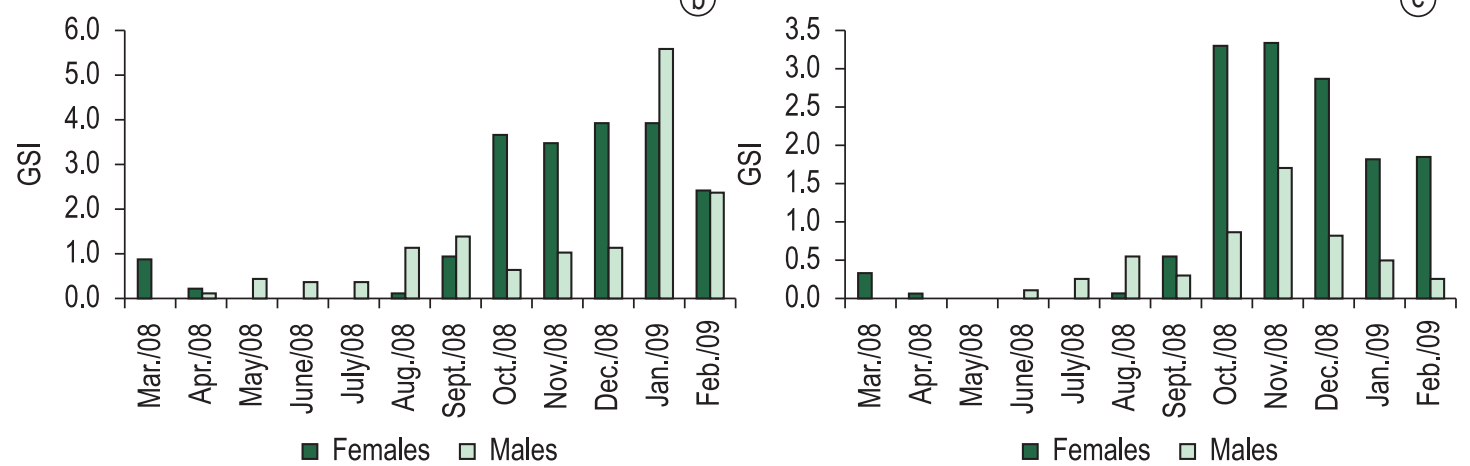

Figure 4. Precipitation (a) and monthly variation of the gonadosomatic index (GSI) of females from net cage site (NC) and reference site (RS) (b); for males in the NC and RS (c) of A. affinis in the Chavantes reservoir, Paranapanema River SP/PR.

Table 2. Results in Reproduction Potential monthly, where: $(\mathrm{n})=$ number of individuals; $(\mathrm{SD})=$ standard deviation; $(\mathrm{DH})=$ Biometrics Horizontal Diameter of oocytes, $(\mathrm{DV})=$ vertical diameter of oocytes and Area of oocytes in population of species $A$. affinis in the sites NC and RS, reservoir Chavantes SP/PR, using Biometry performed with the program QWin Lite 3.1 and LAZ V3 (Leica Application Suite).

\begin{tabular}{|c|c|c|c|c|c|c|c|c|}
\hline \multicolumn{9}{|c|}{ NC } \\
\hline Month & $\mathbf{n}$ & Minimum & Maximum & Average & SD & DH & DV & Area \\
\hline Mar./08 & 9 & 8,267 & 78,557 & 33,370 & 24,035 & 0.63 & 0.62 & 0.27 \\
\hline Apr./08 & 14 & 3,512 & 28,239 & 13,220 & 7,134 & 0.63 & 0.60 & 0.25 \\
\hline May./08 & 3 & 6,678 & 12,816 & 9,280 & 3,173 & 0.56 & 0.63 & 0.24 \\
\hline July./08 & 1 & 2,149 & - & - & - & 0.59 & 0.64 & 0.30 \\
\hline Aug./08 & 74 & 706 & 18,472 & 6,208 & 3,545 & 0.40 & 0.44 & 0.14 \\
\hline Sept./08 & 59 & 4,605 & 25,529 & 12,092 & 4,961 & 0.60 & 0.63 & 0.27 \\
\hline Oct./08 & 58 & 6,466 & 48,214 & 21,870 & 10,671 & 0.59 & 0.65 & 0.28 \\
\hline Nov./08 & 65 & 5,128 & 29,156 & 13,245 & 4,572 & 0.55 & 0.61 & 0.25 \\
\hline Dec./08 & 34 & 7,434 & 29,383 & 16,499 & 5,703 & 0.74 & 0.76 & 0.41 \\
\hline Jan./09 & 95 & 1,350 & 31,536 & 15,242 & 5,659 & 0.70 & 0.72 & 0.36 \\
\hline Feb./09 & 25 & 5,472 & 30,326 & 15,640 & 5,283 & 0.79 & 0.74 & 0.41 \\
\hline \multicolumn{9}{|c|}{ RS } \\
\hline Month & $\mathbf{n}$ & Minimum & Maximum & Average & SD & $\mathrm{DH}$ & DV & Area \\
\hline Mar./08 & 3 & 5,999 & 23,908 & 14,416 & 9,002 & 0.66 & 0.68 & 0.33 \\
\hline Apr./08 & 2 & 10,829 & 37,678 & 24,253 & 18,985 & 0.62 & 0.63 & 0.27 \\
\hline May./08 & 21 & 2,361 & 16,269 & 7,788 & 3,264 & 0.47 & 0.42 & 0.18 \\
\hline July./08 & 14 & 2,708 & 16,851 & 9,871 & 3,816 & 0.65 & 0.61 & 0.36 \\
\hline Aug./08 & 127 & 4,191 & 49,738 & 20,880 & 9,826 & 0.69 & 0.66 & 0.32 \\
\hline Sept./08 & 25 & 4,091 & 28,624 & 14,298 & 6,686 & 0.63 & 0.64 & 0.29 \\
\hline Oct./08 & 14 & 384 & 16,696 & 10,826 & 4,404 & 0.80 & 0.77 & 0.44 \\
\hline Nov./08 & 1 & - & 9,327 & - & - & 0.70 & 0.71 & 0.41 \\
\hline Feb./09 & 12 & 8,169 & 23,932 & 15,994 & 4,354 & 0.68 & 0.73 & 0.38 \\
\hline
\end{tabular}


artificial reservoirs, indicating r-strategist behavior and the ability to adjust to environments altered by humans.

The potential negative impacts caused by fish farming have been assessed in different marine and freshwater environments throughout the world (Beveridge, 1996; Dempster et al., 2002; Menezes and Beyruth, 2003; Machias et al., 2005; Tuya et al., 2006; Brigolin et al., 2009; Romana-Eguia et al., 2010; Dias et al., 2011; Wetengere, 2011). For the effective development of aquaculture in both ecosystems (marine and freshwater), experts agree that the sustainable management requires the involvement and cooperation of the government, academia, private sector, investors, communities and society (Devoe and Hodges, 2002).

Temporal variations in conditions and resources may be predictable or may operate on a time scale ranging from minutes to millennia, which can profoundly influence species richness (Begon et al., 2007). Although the present study did not perform an analysis on the community level, the findings suggest that the input of organic matter (ration) exerts an influence on the population of $A$. affinis residing near the net cages, as evidenced by increased abundance and biomass detected, as well as the insertion of a new food item in their diet (ration), prolonged reproductive period with better physical conditions, and greater reproductive potential.

The conservation and sustainable use of continental waters for fish farming in cages requires knowledge and understanding of the aquatic ecosystem in which they have been installed. Data suggest the need for administrative controls for the establishment of fish farms and monitoring processes to prevent undesired changes in fish assemblages and declines in fish diversity. This study offers a starting point as a tool for the design of future management strategies and plans for the conservation of the study species vis á vis the aquatic ecosystem conditions in which they live.

\section{Acknowledgements}

The authors thank the Fundação de Amparo a Pesquisa (FAPESP) for the scholarship granted to the first author; to Museo Nacional de Ciências Naturales (CSIC), Madrid-Espanha for the threemonth fellowship granted to the first author; to the staff of the Laboratorio de Biologia e Ecologia de Peixes; to the Instituto de Biociências de Botucatu and the Universidade Estadual Paulista for the structure offered for the development of this work.

\section{References}

Agência Paulista de Tecnologia dos Agronegócios APTA. 2008. Pesquisa da APTA faz diagnóstico inédito da piscicultura no Médio Paranapanema. Available from: <http://www.saopaulo.sp.gov.br/spnoticias/ lenoticia.php?id $=92555$ andc $=551$ andq $=$ Pesquisa + $\mathrm{da}+\mathrm{APTA}+\mathrm{faz}+$ diagn $\% \mathrm{~F} 3$ stico+in\%E9dito+da+pi scicultura+no+M\%E9dio+Paranapanema $>$. Access in: 10 jul. 2011.

AGOSTINHO, AA., GOMES, LC. and PELICICE, FM. 2007. Ecologia e Manejo de Recursos Pesqueiros em Reservatórios do Brasil. Maringa: EdUEM. 501 p.

AGOSTINHO, CS., PELICICE, FM., MARQUES, EE., SOARES, AB. and ALMEIDA, DAA. 2011. All that goes up must come down? Absence of downstream passage through a fish ladder in a large Amazonian river. Hydrobiologia, p. 1-12.

BEGON, M., TOWNSEND, CR. and HARPER, JL. 2007. Ecologia de individuos a ecossistemas. Porto Alegre: Artmed. 752 p.

BEVERIDGE, MCM. 1984. Cage and pen fish farming: carrying capacity models and environmental impact. Rome: FAO. 131 p. (Fisheries Techinical Paper).

BEVERIDGE, MCM. 1996. Cage aquaculture. 2nd ed. Oxford: Fishing News Book. 346 p.

BEVERIDGE, MCM. 2004. Cage aquaculture. 3rd ed. Oxford: Fishing News Book. 368 p.

BEVERIDGE, MCM., PHILLIPS, MJ. and CLARKE, RM. 1991. A quantitative and qualitative assessment of wastes from aquatic animal production. In BRUNE, DE. and TOMASSO, JR., eds. Aquaculture and Water Quality. Baton Rouge: The World Aquaculture Society. p. 506-533.

BIALETZKI, A., SANCHES, PV., BAUMGARTNER, G. and NAKATANI, K. 1998. Caracterização morfológica e distribuição temporal de larvas e juvenis de Apareiodon affinis (Steindachner) (Osteichthyes, Parodontidae) no alto Rio Paraná, Paraná. Revista Brasileira de Zoologia, vol.15, no. 4, p. 1037-1047. http://dx.doi.org/10.1590/S010181751998000400021

BIALETZKI, MSA. and NAKATANI, K. 2004. Mudanças ontogênicas no trato digestório e dieta de Apareiodon affinis (Steindachner, 1879) (Osteichthyes, Parodontidae). Acta Scientiarum - Biological Sciences, vol. 26, p. 291-298.

BORGES, PAF., TRAIN, S., DIAS, JD. and BONECKER, CC. 2010. Effects of fish farming on plankton structure in a Brazilian tropical reservoir. Hydrobiologia, vol. 649, p. 279-291. http://dx.doi. org/10.1007/s10750-010-0271-2

BRANDÁO, H., VIDOTTO-MAGNONI, AP., RAMOS, IP. and CARVALHO, ED. 2009. Assessment of the ichthyofauna in sites under the influence of Salto Grande Reservoir (Middle 
Paranapanema River, SP/PR, Brazil). Acta Limnologica Brasiliensia, vol. 21, no. 4, p. 451-463.

Brasil. Ministério da Pesca e Aquicultura - MPA. Aquicultura no Brasil. Brasília, 2009. Disponível em: <http://www.mpa.gov.br/mpa/seap/html/ aquicultura/index.htm>. Acesso em: 25 jan. 2010.

Brasil. Ministério da Pesca e Aquicultura - MPA. Secretaria Especial Aqüicultura e Pesca - SEAP. 2011. Available from: <http://www.mpa.gov.br/mpa/seap/ Jonathan/mpa3/planos_e_politicas/docs/Plano\%20 Mais\%20Pesca\%20e\%20Aquicultura.pdf>.

BRIGOLIN, D., PASTRES, R., NICKELL, TD., CROMEY, CJ., AGUILERA, DR. and REGNIER, P. 2009. Modelling the impact of aquaculture on early diagenetic processes in sea loch sediments. Marine Ecology Progress Series, vol. 388, p. 63-80. http:// dx.doi.org/10.3354/meps08072

BRITTO, SGC. and CARVALHO, ED. 2006. Biological attributes of fish fauna in the Taquaruçu Reservoir, Paranapanema River (Upper Parana, Brazil): composition and spatial distribution. Acta Limnologica Brasiliensia, vol. 18, p. 377-388.

CARROLL, ML., COCHRANE, S., FIELE, R., VELVIN, R. and WHITE, P. 2003. Organic enrichment of sediments from salmon farming in Norway: environmental factors, management practices, and monitoring techniques. Aquaculture, vol. 226, p. 165-180. http://dx.doi.org/10.1016/ S0044-8486(03)00475-7

CARVALHO, ED., DAVID, GM. and SILVA, RJ. 2012. Health and environment in aquaculture. In CARVALHO, ED., SILVA, RJ., RAMOS, IP., PAES, JVK., ZANATTA, AS., BRANDÃO, H., ZICA, EOP., NOBILE, AAA. and DAVID, GS. Ecological features of large neotropical reservoirs and its relation to health of cage reared fish. Rijeka: INTECH. p. 361-382.

CASATTI, L., MENDES, HF. and FERREIRA, KM. 2003, Aquatic macrophytes as feeding site for small fishes in the Rosana reservoir, Paranapanema River, Southeastern Brazil. Brazilian Journal of Biology, vol. 63, p. 213-222. PMid:14509843. http://dx.doi. org/10.1590/S1519-69842003000200006

COSTA, C., IDE, S. and SIMONKA, CE. 2006. Insetos imaturos: metamorfose e identificação. Ribeirão Preto: Holos Editora. 249 p.

CUSHING, DH. 1981. Fisheries biology: a study in population dynamics. University of Winconsin Press. 295 p.

DALSGAARD, T. and KRAUSE-JENSEN, D. 2006. Monitoring nutrient release from fish farms with macroalgal and phytoplankton bioassays. Aquaculture, vol. 256, p. 302-310. http://dx.doi. org/10.1016/j.aquaculture.2006.02.047

DEMPSTER, T., SANCHEZ-JEREZ, P., BAYLESEMPERE, JT., GIMÉNEZ-CASALDUERO, F. and VALLE, C. 2002. Attraction of wild fish to seacage fish farms in the south-western Mediterranean Sea: spatial and short-term temporal variability. Marine Ecology Progress Series, vol. 242, p. 237-252. http://dx.doi.org/10.3354/meps242237

DEVOE, MR. and HODGES, CE. 2002. Management of marine aquaculture: the sustainability challenge. Marine Aquaculture, South Carolina USA, vol. 2 p. 21-49.

DIAS, JHP. and GARAVELLO, JC. 1998. Biological studies on the fish community of Salto Grande Reservoir, Paranapanema River Basin, São Paulo, Brazil. Verhandlungen - Internationale Vereinigung für theoretische und angewandte Limnologie, vol. 26, p. 2228-2231.

DIAS, JD., TAKAHASHI, EM., SANTANA, NF. and BONECKER, CC. 2011. Impact of fish cage-culture on the community structure of zooplankton in a tropical reservoir. Iheringia - Série Zoologia, vol. 101, no. 1-2 p. 75-84.

DUKE ENERGY. 2002. Relatório para licenciamento ambiental da usina hidrelétrica de Chavantes. v. 1.

GIANNOULAKI, M., MACHIAS, A., SOMARAKIS, S. and KARAKASSIS, I. 2005. Wild fish spatial structure in response to presence of fish farms. Journal of the Marine Biological Association of the United Kingdom, vol. 85, p. 1271-1277. http://dx.doi. org/10.1017/S0025315405012427

GJEDREM, T. 2012. Genetic improvement for the development of efficient global aquaculture: A personal opinion review. Aquaculture, vol. 344-349, p. 12-22.

GODINHO, PH. 2007. Estratégias de peixes aplicadas à aqüiculturas: bases para o desenvolvimento de tecnologias de produção. Revista Brasileira de Reprodução Animal, vol. 31, no. 3, p. 351-360.

GOMIERO, LM. and BRAGA, FMS. 2005. The condition factor of fishes from two river basins in São Paulo state, Southeast of Brazil. Acta Scientiarum - Biological Sciences, vol. 27, p. 73-78.

GURGEL, HCB. 2004. Estrutura populacional e época de reprodução de Astyanax fasciatus (Cuvier) (Characidae, Tetragonopterinae) do rio Ceara Mirim, Poço Branco, Rio Grande do Norte, Brasil. Revista Brasileira de Zoologia, vol. 21, p. 131-135. http:// dx.doi.org/10.1590/S0101-81752004000100022

HAHN, NS., AGOSTINHO, AA., GOMES, LC. and BINI, LM. 1998. Estrutura trófica da ictiofauna do reservatório de Itaipu (Paraná-Brasil) nos primeiros anos de sua formação. Interciencia, vol. 23, no. 5, p. 299-305.

HÅKANSON, L., CARLSSON, L. and JOHANSSON, J. 1998. A new approach to calculate the phosphorus load to lakes from fish farm emissions. Aquaculture Engineering, vol. 17, p. 149-166. http://dx.doi. org/10.1016/S0144-8609(97)00018-6 
HÅKANSON, L. 2005. Changes to lake ecosystem structure resulting from fish cage farm emissions. Lakes and Reservoirs: Research and Manage, vol. 10, p. 71-80. http://dx.doi.org/10.1111/j.14401770.2005.00253.x

HENRY-SILVA, GG. and CAMARGO, AFM. 2008. Impacto das Atividades de Aqüicultura e Sistemas de Tratamento de Efluentes com Macrófitas Aquáticas - Relato de Caso. Boletim do Instituto de Pesca, vol. 34, p. 163-173.

KARR, JR. 1981. Dudley D. R. Biological perspectives on water quality goals. Environmental Management, vol. 5, p. 55-68. http://dx.doi.org/10.1007/ BF01866609

KARR, JR. and CHU, EW. 2000. Sustaining living Rivers. Hydrobiologia, vol. 422, no. 423, p. 1-14.

KAWAKAMI, E. and VAZZOLER, G. 1980. Método gráfico e estimativa de índice alimentar aplicado no estudo de alimentação de peixes. Boletim Instituto Oceanográfico, vol. 29, no. 2, p. 205-07. http://dx.doi. org/10.1590/S0373-55241980000200043

KING, M. 2007. Fisheries Biology, Assessment and Management. 2. ed. Blackwell Publishing. 382 p.

KUTTI, TA. 2008. Aqüicultura estimulando a vida animal. Panorama da Aqüicultura, vol. 18, p. 18-19.

LACHI, GB. and SIPAÚBA-TAVARES, LH. 2008. Qualidade da Água e Composição Fitoplanctônica de um Viveiro de Piscicultura Utilizado para Fins de Pesca Esportiva e Irrigação. São Paulo. Boletim Instituto de Pesca, vol. 34, p. 29-38.

LATINI, AO. and PETRERE JUNIOR, M. 2004. Reduction of native fish fauna by alien species: an example from Brazilian freshwater tropical lakes. Fisheries Management and Ecology, vol. 11, p. 71-79. http://dx.doi.org/10.1046/j.13652400.2003.00372.x

MACHIAS, A., KARAKASSIS, I., LABROPOULOU, M., SOMARAKIS, S. and PAPADOPOULOU, KN. 2004. Changes in wild fish assemblages after the establishment of a fish farming zone in an oligotrophic marine ecosystem. Estuarine, Coastal and ShelfScience, vol. 60, p. 771-779. http://dx.doi. org/10.1016/j.ecss.2004.03.014

MACHIAS, A., KARAKASSIS, I., SOMARAKIS, S., GIANNOULAKI, M., APADOPOULOU, KN. and SMITH, C. 2005. Response of demersal fish communities to the presence of fish farms. Marine Ecology Progress Series, vol. 288, p. 241-250. http:// dx.doi.org/10.3354/meps288241

MANNINO, AM. and SARA, G. 2008. Effects of fishfarm biodeposition on periphyton assemblages on artificial substrates in the southern Tyrrhenian Sea (Gulf of Castellammare, Sicily). Aquatic Ecology, vol. 42, p. 575-581. http://dx.doi.org/10.1007/ s10452-007-9131-1
MENEZES, LCB. and BEYRUTH, Z. 2003. Impactos da aqüicultura em tanques-rede sobre a comunidade bentônica de Guarapiranga - São Paulo - SP. Boletim Instituto de Pesca, vol. 29, p. 77-86.

MERRITT, RW. and CUMMINS, KW. 1996. An introduction to the aquatic insects of North America. 3rd ed. Dubuque: Kendall Hunt Publ. Co. 722 p.

NAIK, DR., BOSUKONDA, S. and MRUTYUNJAYAREDDY, K. 2011. Reservoir Impact Assessment on Land Use/Land Cover and Infrastructure - A Case Study on Polavaram Project. Journal of the Indian Society of Remote Sensing, vol. 39, no. 2, p. 271-278. http://dx.doi.org/10.1007/ s12524-011-0086-2

NELSON, JS. 1994. Fishes of the world. 3rd eds. New York: John Wiley and Sons. 600 p.

NICKELL, LA., BLACK, KD., HUGHES, DJ., OVERNELL, J., BRAND, T., NICKELL, TD., BREUER, E. and HARVEY, SM. 2003. Bioturbation, sediment fluxes and benthic community structure around a salmon cage farm in Loch Creran, Scotland. Journal of Experimental Marine Biology Ecology, vol. 285, no. 286, p. 221-233.

ONO, EA. and KUBITZA, F. 2003. Cultivo de peixes em tanques-rede. Jundiaí. 112p.

PAVANELLI, GC., EIRAS, JC. and TAKEMOTO, RM. 2008. Doenças de peixes profilaxia, diagnóstico e tratamento. Maringá: Eduem. 311 p.

RATTON, TF., BAZZOLI, N. and SANTOS, GB. 2003. Reproductive biology of Apareiodon affinis (Pisces: Parodontidae) in the Furnas Reservoir, Minas Gerais, Brazil. Journal Applied Ichthyology, vol. 19, p. 387-390. http://dx.doi.org/10.1111/j.14390426.2003.00485.x

REIS, RE., KULLANDER, SO. and FERRARIS, JRCJ. 2003. Check list of the freshwater fishes of South and Central America. Porto Alegre: EdiPUCRS. 742 p.

ROMANA-EGUIA, MRR., IKEDA, M., BASIAO, ZU. and TANIGUCHI, N. 2010. Growth comparison of Asian Nile and red tilapia strains in controlled and uncontrolled farm conditions. Aquaculture International, vol. 18, p. 1205-1221. http://dx.doi. org/10.1007/s10499-010-9334-7

ROSET, N., GRENOUILLET, G., GOFFAUX, D. and PONT, D. 2007. A review of existing fish assemblage indicators and methodologies. Fisheries Management and Ecology, vol. 14, p. 393-405. http://dx.doi. org/10.1111/j.1365-2400.2007.00589.x

SALES-LUÍS, T., FREITAS, D. and SANTOS-REIS, M. 2009. Key landscape factors for Eurasian otter Lutra lutra visiting rates and fish loss in estuarine fish farms. European Journal of Wildlife Research, vol. 55, p. 345355. http://dx.doi.org/10.1007/s10344-009-0250-y

SANTOS, EP. 1978. Dinâmica de populaçôes aplicada à pesca e piscicultura. São Paulo: EdUSP. 129 p. 
SANTOS, SL., VIANA, LF. and LIMA-JUNIOR, SE. 2006. Fator de condição e aspectos reprodutivos de fêmeas de Pimelodella cf. gracilis (Osteichthyes, Siluriformes, Pimelodidae) no rio Amambai, Estado de Mato Grosso do Sul. Acta Scientiarum Biological Sciences, vol. 28, no.2, p.129-134.

SHIBATTA, OA., ORSI, ML., BENNEMANN, EST. and SILVA-SOUZA, AT. 2002. Diversidade e distribuição de peixes na bacia do rio Tibagi. In MEDRI, ME., SHIBATTA, OA., BIANCHINI, E. and PIMENTA, JA., eds. A Bacia do Rio Tibagi. Londrina. p. 425-432.

SIMON, TP. and LYONS, J. 1995. Application of the index of biotic integrity to evaluate water resource integrity in freshwater ecosystems. In DAVIS, WS. and SIMON, TP. Biological assessment and criteria: Tools for water resource planning and decision making. Boca Raton: CRC Press. 415 p.

STRIXINO, G. and STRIXINO, ST. 1982. Insetos aquáticos: guia de identificaçâo. São Carlos: Universidade Federal de São Carlos. 21 p.

TEIXEIRA, I. and BENNEMANN, ST. 2007. Ecomorfologia refletindo a dieta dos peixes em um reservatório no sul do Brasil. Biota Neotropica, vol. 7 , p, 67-76.

TUYA, F., SANCHEZ-JERES, P., DEMPSTER, T., BOYRA, A. and HAROUN, RJ. 2006. Changes in demersal wild fish aggregations beneath a sea-cage farm after the cessation of farming. Journal of Fish Biology, vol. 69, no. 3, p. 682-697. http://dx.doi. org/10.1111/j.1095-8649.2006.01139.x

VAZZOLER, AE. 1996. Biologia da reprodução de peixes teleósteos: teoria e prática. Maringá: EDUEM. 169 p.
VEREGUE, AM. and ORSI, ML. 2003. Biologia reprodutiva de Astyanax scabripinnis paranae (Eigenmann) (Osteichthyes, Characidae), do ribeirão das Marrecas, bacia do rio Tibagi Paraná. Revista Brasileira de Zoologia, vol. 20, p. 97-105.

VIDOTTO-MAGNONI, AP. and CARVALHO, ED. 2009. Aquatic insects as the main food resource of fish the community. Neotropical Ichthyology, vol. 7, p. 701-708. http://dx.doi.org/10.1590/S167962252009000400020

WETENGERE, K. 2011. Socio-economic factors critical for intensification of fish farming technology. A case of selected villages in Morogoro and Dar es Salaam regions, Tanzania. Aquaculture International, vol. 19, p. 33-49. http://dx.doi.org/10.1007/s10499-0109339-2

YOKOYAMA, H. 2003. Environmental quality criteria for fish farms in Japan. Aquaculture, vol. 226, no. 12, p. 45-56. http://dx.doi.org/10.1016/S00448486(03)00466-6

ZAMBRANO, L., VALIENTE, EM. and ZANDEN, JV. 2010. Food web overlap among native axolotl (Ambystoma mexicanum) and two exotic fishes: carp (Cyprinus carpio) and tilapia (Oreochromis niloticus) in Xochimilco, Mexico City. Biological Invasions, vol. 12, p. 3061-3069. http://dx.doi.org/10.1007/ s10530-010-9697-8

ZANATTA, AS., RAMOS, IP., SILVA, RJ., LANGEANI, F. and CARVALHO, ED. 2010. Pisces, Siluriformes, Ictaluridae, Ictalurus punctatus (Rafinesque, 1818): first record in middle Paranapanema River reservoir, aquaculture and exotic species dispersion. Check List, vol. 6, p. 589-591.

ZAR, JH. 1984. Biostatistical Analysis Prentince-Hall Editions. 718 p. 